\title{
THE IMPORTANCE OF UNIVERSITY IN THE PREPARATION OF THE NEW GENERATION OF GEOGRAPHY TEACHERS IN ALBANIA
}

DOI: http://dx.doi.org/10.18509/GBP.2019.79

UDC: 377.091.011.3-051(496.5)

\author{
Albana Kosovrasti \\ Faculty of History and Philology, Department of Geography, \\ University of Tirana, Albania
}

The education system in Albania, after 1990, has undergone some reforms both in the pre-university and university systems, reforms that were necessary due to the important socio-economic and cultural changes during the transition from the dictatorship to the democratic system.

These reforms have affected and changed the role and position of Geography subject in the pre-University as well in the University curricula. These changes have been evident in the changing of numbers of weekly hours, content, perspectives of future development and in some specific topics. This paper aims to analyze the quantity and quality of these changes and to identify their direct impact in the geographic knowledge of the new generation of pupils and students of geography. Frequent changes have also occurred in the recruitment scheme of students at the university, bringing uncertainty and fluctuation of different levels from one year to the next.

The involvement and implementation of Bologna system in the Albanian Universities brought many changes in the education curricula, teaching methodology, collaboration with foreign universities, diplomas, etc.

From this point of view, considering the main issues faced by our University education system such as: the large number of students in the auditorium; the lack of laboratories; modern libraries; etc., it is important to analyze the importance and the role of the University in the professional formation of new teachers of Geography.

Key words: reform, curriculum, vocational education, criteria, standards

\section{SOME IMPORTANT LEGAL DOCUMENTS DRAFTED BY MINISTRY FOR EDUCATION, SPORT AND YOUTH OF ALBANIA FOR VOCATIONAL EDUCATION OF YOUNG TEACHERS}

The vocational education of young teachers in Albanian universities is becoming more and more important, influenced by the frequent changes in the pre-university education's law and curriculum. Therefore these changes, there have been some reshaping of the vocational master curriculum at many faculties of UT, to extract qualitative teachers from their audiences.

The higher education and research system will create, develop and transmit knowledge through teaching, relevant research and service provision. It will assist economic development and contribute to higher standards of democracy and citizenship [1].

Albanian universities were included in the Bologna system in 2003 and since this year and onwards, apart from the changes in their curriculum structure, with the aim of its approximation to EU countries, there has been a steady increase in the number of students in auditoriums.

The strategy for higher education is critical for the process of modernisation of Albanian higher education institutions, but obviously it is not easy to follow. On the one hand, 
Albanian higher education institutions are engaged in a process of reforms as part of the Bologna process, which still absorbs most staff energies. On the other hand, the traditional academic culture does not facilitate the interest of academics in these less traditional activities. Finally, a process like this needs both trained people and incentives for starting up the first initiatives. [2].

The quality of teaching depends on the quality of the academic staff doing the teaching, but also, and almost as important, on the way in which they do their teaching. Neither aspect of quality can be measured only by qualifications, each also needs qualitative judgements - which is the main function of a quality assurance process [3].

The massive enrollment in the education system should be a global phenomenon, because the service provider's today offer possibilities for all, saying this, in principle, no one has the right to enforce the individuals to elect the type of education they want to have [4]. This had its positive side by increasing the percentage of the population with higher education, but on the other hand seriously damaged the quality of their education.

As of today (2015), Albania remains one of the countries that spends the smallest proportion of its GDP, around 0.6 percent, on higher education. This means that while higher education has become more accessible to larger numbers, its quality has suffered dramatically. [5].

It would be nice if it were true that "we are quality" but we notice that our students, even when through friendly information networks, find an occupation in any European state, need a year of additional studies to recover or fill missing knowledge because of the system, or of the non-recognition of the Higher Education Institution that has given the diploma. The Albanian University does not only not respond to today's Western knowledge needs but fails to teach students how to learn [6].

The quality of the universities and the paths that must be followed in order to guarantee it are today the main themes of the intellectual debate currently taking place in Albania. Part of this debate is even the Law on Higher Education approved by the Albanian government in 2015.

In this context, the MEAS of Albania has issued a series of legal documents such as the Decision of the Council of Ministers of Albania no. 216, dated 20 April 2018, which claims that the average grade of pre-university studies of students entering universities with a teaching branch must be 7 and not 6 like in the other branches. This instruction has increased the quality of students studying in different branches of teaching.

Being a teacher is the most important profession that influences the schooling of the next generation and needs to be formed and developed based on standards that determine what each teacher should know, which skills should be demonstrated and what attitudes and values should be featured [7].

Drafting and approval of Initial Teacher Standards, Professional Standards of Teachers AMU( low-mid Education) and AML (mid-high education) etc. constitute a good legal platform on which curricula and programs for professional master in different teaching branches are based, by clearly specifying the skills and knowledge that the student should have in his / her formation as a teacher.

Initial Teacher Training (ITT) is considered as a starting point in the ongoing professional development process. It sets the foundation of the journey towards the profession and career of the teacher [8].

The concept and process of professional development of teachers in Albania includes several phases: 
a. the initial training phase, which is carried out at university auditors b. the internship stage, conducted by universities in cooperation with the directorates of pre-university education schools, 6-8 weeks of teaching. Equally important in the vocational education of new teachers is the 1 year internship they perform after graduation

c. the stage of continuous development along the career. Teachers come up with some tests to get relevant categories as well as many trainings for getting to get informed about the latest developments in relevant fields, new teaching methods, and so on.

Professional standards of initial teachers are built and organized in 3 main areas of professional development:

1. Knowledge and professional understanding due to the initial teacher should have a good understanding of the curriculum and its changing processes in school, teaching planning, evaluation principles, etc.

2. Skills and professional expression related to the abilities and skills that the teacher demonstrates in relation to planning of teaching and learning, selection of teaching strategies and resources to respond to pupils' needs and skills, enabling of a safe learning environment, data's gathering and reporting as an integral part of the teaching process. 3. Professional Values and Personal Engagement. The values are complex and are the ideals according to which the teacher forms his practice as a professional [9].

All of these standards are clearly reflected in Professional Master in Education curricula in various branches of Albanian universities.

\section{STUDENT ADMISSION'S PROCESS IN ALBANIAN UNIVERSITIES}

The process of University admission in Albania has changed multiple times. However, since 2005 the admission is done based on the results of the "Matura Shtetërore" (State Matura) exams and on specific criteria stated by the faculties and different study courses. The "Matura Shtetërore" includes compulsory as well as non-compulsory exams at the end of high school, thus representing not only the final exams, but also a process of regulations of the transition from a secondary school to Public Institutions for higher Education (PIHE) [10].

Using the same concepts, different faculties determine their preferred subjects that share a close relationship with their field of study and the percentage that every subject shares. The Faculty of History and Philology has stated that for all of its study-courses, $80 \%$ of all points given to the student will be attributed to the average grade of three years of High School and the remaining 20\% from the average of the exams of "Matura Shtetërore". The Faculty of Economy uses a different approach: $50 \%$ of the given points is attributed to the average grade of three years of High School, $15 \%$ is attributed to Math, $15 \%$ to Economy, $10 \%$ to Physics and $10 \%$ to the Foreign language of choice.

All the students with an average grade higher than 6 can apply to a University, with an exception for the study-courses that include teaching, where the average grade should be higher than 7. This has to do with the facts that in these faculties are better students than those before. The students have the right to apply for up to 10 different study courses, through an online system.

However, from a questionnaire with the students enrolled for the study course of Geography during the years comes up that for $70 \%$ of them, Geography was not in their top 5 desired degree program and this will be shown in their results, as Geography was not their most preferred subject. 


\section{THE PROGRESS OF THE STUDENTS IN PROFESSIONAL MASTER IN EDUCATION, IN GEOGRAPHY (FHF/UT)}

In 2018, teaching was declared a priority in the higher Education from the Albanian Government. According to that, all the excellent students that selected Teaching for the academic year 2018-2019, will not pay any fees and they will be granted a $\$ 1000$ a year scholarship, which will follow if their results are satisfying.

This led to a massive registration during this academic year, at the faculties offering a Masters in Teaching: 260 students with an average grade over 9 and 3700 over 7, which will give us a new generation of qualitative teachers' [11].

In the following table is shown the progress of the students that enrolled for 2018-2019 at the Professional Master in Education in the degree program of Geography in FHF of the UT.

A general increase in the number of students can be noticed, up until the academic year 2017-2018, which is three times higher compared to the year 2008-2009: from 47 to 177 students.

During this academic year alone (2018-2019), there have been only 134 registrations in Professional Master in Education. This drop is related to two main reasons:

1. The Implementation of the average grade of 7 for the pursuing of the studies at Professional Master in Education and,

2. The Opening of another professional Masters in GIS.

The Percentage of the students graduated varies from $78.2 \%$ in the year 2015-2016 to $100 \%$ in the year 2008-2009. The results are high, but the same cannot be said for the average, which with slight increases during the last years sticks to 7 .

It is important to emphasize, that during the 2017 - 2018 academic year, 12 students have finished the first year studies for Professional Master in Education with an average result above 9.0. 17 others with an average result between $8.5-9.0$ and 20 students with an average result between $8.0-8.5$. Also, throughout the 2018 - 2019 academic year, 40 students were graduated with an average result above 8.0 [12].

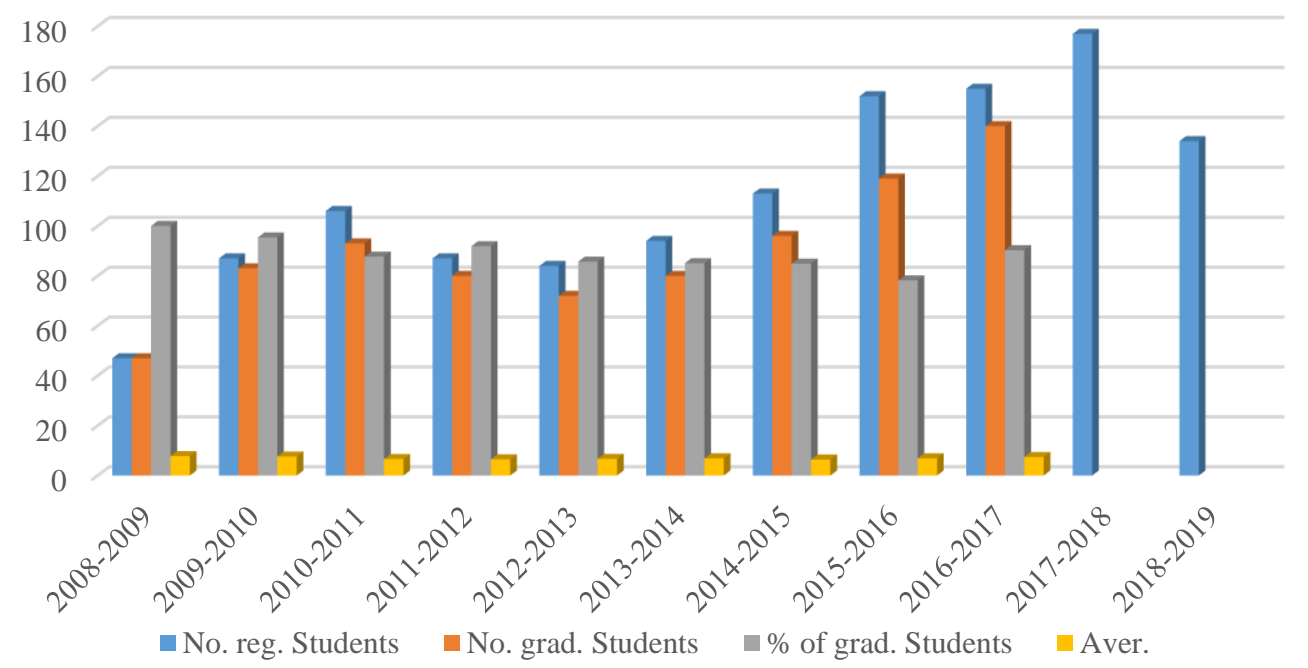

Figure 1. The number of registered students graduated in Professional Master in Education, Degree Program Geography, The Faculty of History and Philology, UT, 2008-2019

Related to these statistics, we can surely say that the quality of students, who tomorrow will be the next generation of the geography teachers, is entering a new and better phase. 
The results are expressed related to the grading system used in Albania. ( 4 - 10, where 4 is the lowest grade and 10 is the highest)

\section{CONCLUSION:}

1. The frequent reforms in which the higher education system in Albania has been included have brought Uncertainty and have become an obstacle to quickly reflecting upon those and to having a qualitative education system.

2. The decision of Ministry for Education, Sport and Youth of Albania in 2018 to increase the average grade of the students applying in Teaching, over 7 will increase the quality of the new teachers.

3. The Drafting of platforms or different legal documents as standards for new teachers, professional teaching standards AMU and AML and so on will positively impact on having a new generation of more professional and qualitative teachers.

4. The Reliance on the best models of European Universities has significantly improved the curriculum of Masters in Teaching and this will be shown in having more professional teachers in the future.

Aiming to increase the role of the University in the education of professional teachers we recommend:

1. A further improvement of the curriculum in the Masters Programs in Teaching in order to increase the quality of young teachers.

2. It is also necessary to make the curriculum as similar as possible with the same program of the Universities in the EU. This would increase the number of students applying in common projects or short-term transferring their studies to other Universities with Erasmus + and other funding programs.

3. The admission process in some faculties or in specific courses must change in order to reflect the changes done in the college and high school curriculum.

4. There should be done more in order to motivate the students for higher results through the improvement of the scholarship system for the excellent students or better employment opportunities after the studies.

5. There should be more studies on the education work-market in Albania taking in consideration also the decrease of the number of births and as a consequence the decrease on the number of students. This would help to decide better on the number of students to be enrolled in professional Master for Teacher and would create more opportunities for their employment after finishing the studies.

\section{REFERENCES}

[1]. World Data on Education $7^{\text {th }}$ edition 2010/2011, pp 2.

[2]. Vidal J.,\& Ferrei C., \& Vieira M.J, Mora J.G. Higher education in Albania: developing third mission activities, Article in Tertiary education and Management, February 2015, pp 7

To link to this article: http://dx.doi.org/10.1080/13583883.2014.994556

[3]. Hatakenaka S. \&Thomson Q. Albania Higher Education, Report submitted to the European Investment Bank March 2006, pp 14-15.

[4]. Gjura T. Higher Education in Albania, past and present, Panorama Newspaper 25.06.2012. Tirana, Albania

[5]. Kajsiu B., Higher Education in Albania: The never Ending Challenge. Internacional Higher Education. Number 82.Fall 2015. pp 15-16 
[6]. Fuga A. University of Tirana. I am today on strike, Standard Newspaper 18.01.2019. Tirana, Albania

[7]. Professional standards of general training and subject matter of the teacher in lower secondary education and upper secondary education. Ministry for Education, Sport and Youth of Albania, Tirana 2016 pp. $2-25$

[8]. Professional standards of initial teacher, Ministry for Education, Sport and Youth of Albania Tirana 2016, pp 5-7.

[9]. Professional standards of initial teacher, Ministry for Education, Sport and Youth of Albania Tirana 2016, pp 7-11

[10]. Official website of Ministry for Education, Sport and Youth of Albania

[11].The statistic office at Ministry for Education, Sport and Youth of Albania, November 2018

[12]. The secretariat of Professional Master in Education, Faculty of History and Philology, University of Tirana, Albania. January 2019 